\title{
Construction and development of an auto-regulatory gene expression system in Bacillus subtilis
}

Chengran Guan' ${ }^{1}$ Wenjing Cui ${ }^{*}$, Jintao Cheng ${ }^{1}$, Li Zhou', Junling Guo ${ }^{1}$, Xu Hu', Guoping Xiao ${ }^{2}$ and Zhemin Zhou $^{*}$

\begin{abstract}
Background: Bacillus subtilis is an all-important Gram-positive bacterium of valuable biotechnological utility that has been widely used to over-produce industrially and pharmaceutically relevant proteins. There are a variety of expression systems in terms of types of transcriptional patterns, among which the auto-inducible and growthphase-dependent promoters are gaining increasing favor due to their inducer-independent feature, allowing for the potential to industrially scale-up. To expand the applicability of the auto-inducible expression system, a novel auto-regulatory expression system coupled with cell density was constructed and developed in B. subtilis using the quorum-sensing related promoter srfA $\left(\mathrm{P}_{\text {srf }}\right)$.
\end{abstract}

Results: The promoter of the srf operon was used to construct an expression plasmid with the green fluorescent protein (GFP) downstream of $\mathrm{P}_{\text {srfa }}$. The expression displayed a cell-density-dependent pattern in that GFP had a fairly low expression level at the early exponential stage and was highly expressed th the late exponential as well as the stationary stages. Moreover, the recombinant system had a similar expression pattern in wild-type B. subtilis 168, WB600, and WB800, as well as in B. subtilis 168 derivative strain 1681, with the complete deletion of $\mathrm{P}_{\text {sff } A}$, indicating the excellent compatibility of this system. Noticeably, the expression strength of $P_{\text {srfa }}$ was enhanced by optimizing the -10 and -35 core sequence by substituting both sequences with consensus sequences. Importantly, the expression pattern was successfully developed in an auto-regulatory cell-density coupling system by the simple addition of glucose in which GFP could not be strongly expressed until glucose was depleted, resulting in a greater amount of the GFP product and increased cell density. The expression system was eventually tested by the successful over-production of aminopeptidase to a desired level.

Conclusion: The auto-regulatory cell density coupling system that is mediated by $\mathrm{P}_{\text {srfa }}$ is a novel expression system that has an expression pattern that is split between cell-growth and over-expression, leading to an increase in cell density and elevating the overall expression levels of heterologously expressed proteins. The broad applicability of this system and inducer-free expression property in B. subtilis facilitate the industrial scale-up and medical applications for the over-production of a variety of desired proteins.

Keywords: Bacillus subtilis, Protein expression system, Promoter, Quorum sensing, Auto-inducible, Auto-regulatory, Over-production, srf operon

\footnotetext{
*Correspondence: wjcui@jiangnan.edu.cn; zhmzhou@jiangnan.edu.cn

1 School of Biotechnology, Key Laboratory of Industrial Biotechnology (Ministry of Education), Jiangnan University, 1800 Lihu Road, Wuxi, Jiangsu 214122, China

Full list of author information is available at the end of the article
} 


\section{Background}

Bacillus subtilis, a rod-shaped Gram-positive soil bacterium, has been regarded to be a "generally recognized as safe" (GRAS) microbe that can naturally secrete numerous extracellular proteins. These properties make this bacterium to be one of the most popular hosts for naturally producing a variety of enzymes and over-expressing a large number of pharmaceutical and industrial recombinant proteins of interest, such as amylase [1-4], lipase [5], alkaline PGL [6], and so on. The major advantages of B. subtilis compared to other protein expression hosts are that the host has high-cell-density growth and can secrete proteins directly into the cultural medium, which greatly simplifies the following steps for purification and preparation.

The most commonly used expression systems in $B$. subtilis are inducible expression systems that contain inducer-specific promoters, such as the T7 promoter; grac promoter; spac promoter induced by isopropyl$\beta$-D-thiogalactopyranoside (IPTG); $x y l \mathrm{~A}$ promoter driven by xylose; $S a c B$ promoter induced by sucrose; and $\alpha$-amylase promoter transcribed in response to starch $[4,7,8]$. Although a variety of homologous and heterologous proteins have been successfully over-produced in B. subtilis under the control of these inducible promoters, a noticeable basal expression level was observed from these expression systems. Moreover, the high cost of inducers that need to be added to the medium during fermentation at a large scale would limit the industrial utilization of these protein expression systems. Recently, two strictly inducible systems, the subtilin-regulated expression (SURE) system and the LiaRS-controlled expression system (LIKE), which rely on the regulation of the promoter for the spa-box and the cell envelope stress-responsive liaI promoter, respectively, have been developed for scientific and industrial applications. Both of these protein expression systems are strictly controlled by the addition of lantibiotic subtilin and bacitracin, respectively, after the exponential phase of cell growth, preventing the leakage of transcription under non-inducing conditions $[9,10]$.

To avoid the addition of any inducers, promoters under the control of a variety of environmental stresses, such as heat shock, salt, acid, and ethanol stresses, as well as oxygen or glucose starvation [11-13], have also been used to construct systems for the expression of a variety of proteins in B. subtilis, none of which, could be used to over-produce industrially and pharmaceutically utilized proteins and enzymes because of the low and non-persistent expression levels of these systems as well as the difficulty of controlling protein expression. Very recently, an artificial auto-inducible system using a growth-phase promoter (cry3Aa promoter, transcribed during the stationary phase) and another expression system using the nutrient starvation response promoter (pst promoter, responded to phosphate starvation) $[14,15]$ were developed and characterized. Importantly, a self-inducible system for the reliable and low-cost over-production of recombinant proteins has been developed by using the manP-encoding phosphotransferase system (PTS), which is under the control of the relatively strong and strict promoter manP; manP is transcribed during a glucoselimited process in the engineered B. subtilis strain TQ356 [16]. The self-controlled system is suitable for highcell-density fermentation because cell growth and overexpression are discrete at different stages.

Bacterial quorum sensing (QS) systems are cell-density-dependent regulatory networks that coordinate bacterial behavioral changes from single cellular organisms at low cell densities to multicellular organisms when their population density reaches a threshold level. The two peptides, ComX and CSF, mediate the quorum sensing control of competence and sporulation in B. subtilis. The accumulation of a high concentration of peptides in the late-growth phase triggers a series of gene transcription events downstream of the ComA-ComP two-component system in the cell [17], among which the $\operatorname{srf}$ operon is stimulated via a complex-regulation phosphorylated cascade (Fig. 1) [18]. As a monitor of cell density, the ComX pheromone is expressed, transported and accumulated in the broth along with cell growth. When the cells reach a certain density, the ComX pheromone reaches the obligatory concentration to activate the signal transduction system, which is composed of the two-component regulatory proteins ComP and ComA, and finally, phosphorylated ComA binds to the promoter $\left(\mathrm{P}_{\text {srfA }}\right)$ of the srf operon to activate the transcription of corresponding gene expression [19-21], leading to temporally controllable transcription.

Inspired by the transcriptional pattern of $\mathrm{P}_{\text {srfA }}$, a novel gene expression system in B. subtilis was developed and characterized by harnessing the transcriptional properties of $\mathrm{P}_{\text {srfA }}$ as controlled through the response to cell density and glucose concentration during culturing. Gene expression under the control of the promoter was significantly inhibited via the addition of an appropriate concentration of glucose at the cell-growth phase until glucose was depleted, permitting the coupling of gene expression to cell density and the concentration of glucose. The functionality was examined by the efficient and controllable expression of GFP and aminopeptidase (AP). This auto-regulatory expression system could be used as an efficient tool for gene over-expression in B. subtilis. 


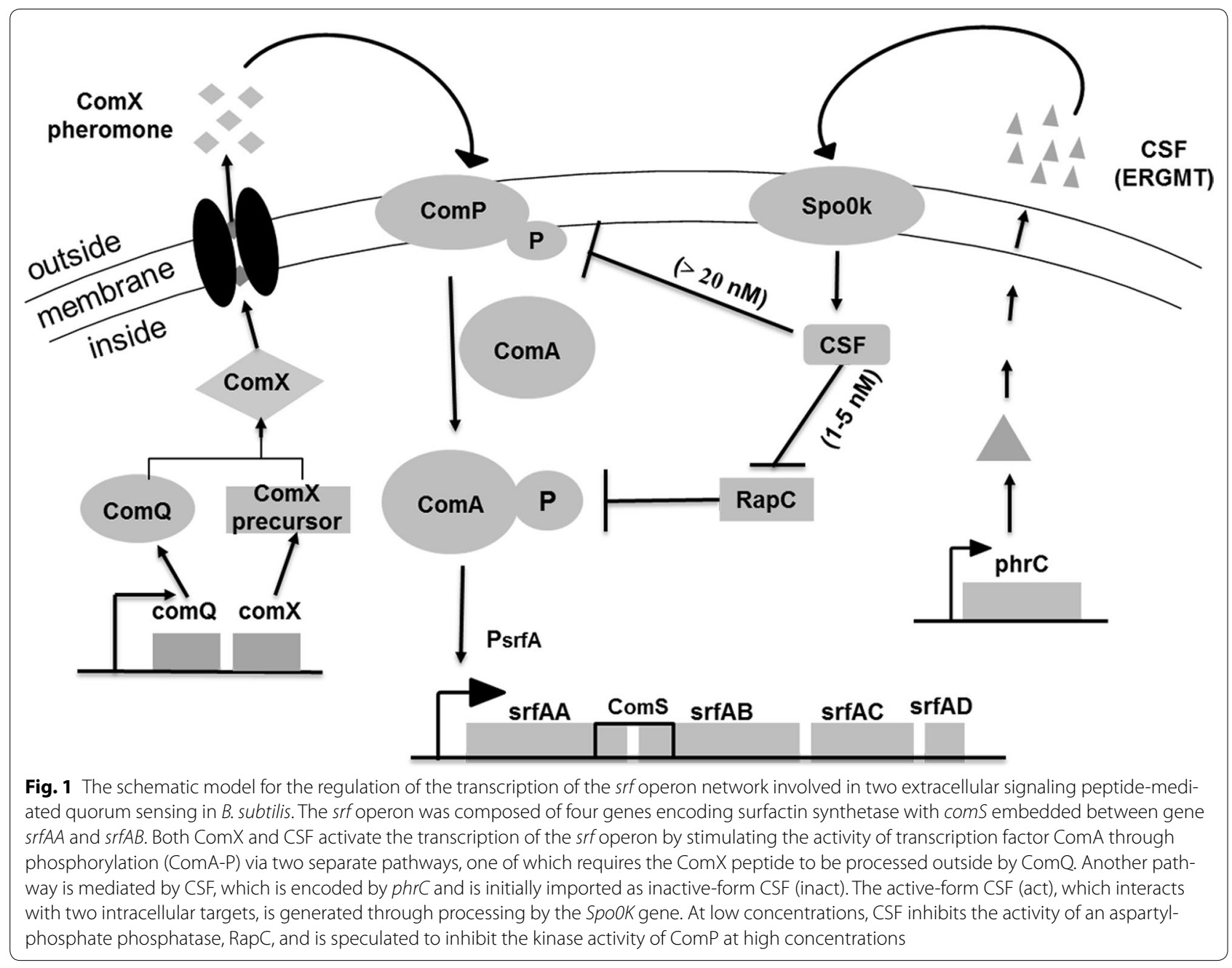

\section{Results and discussion}

Expression pattern of GFP under the control of $\mathrm{P}_{\text {srfa }}$ in $B$. subtilis 168

In recent years, several types of expression systems that are free of inducers via a variety of transcriptional patterns have been developed in B. subtilis or other Gram-positive hosts to over-express industrially and pharmaceutically used proteins $[13,15,16]$. To expand the application of self-inducible or auto-inducible gene expression systems in B. subtilis, a novel recombinant plasmid, pBSG03, harboring a cell-density-responsive promoter, $\mathrm{P}_{\text {srfA }}$, upstream of the reporter protein GFP was constructed, permitting the monitoring of gene expression in the hosts. To characterize the expression pattern and strength for $\mathrm{P}_{\text {srfA }}$, pBSG03 was transformed into B. subtilis 168 and then cultivated in Terrific Broth (TB) medium for $40 \mathrm{~h}$, during which the culture was sampled periodically to examine the expression level of GFP. The results demonstrate that the expression level of GFP was considerably low from the lag phase to the early exponential phase. Subsequently, the expression level increased sharply when cell growth entered the late exponential phase. Thereafter, the expression level increased gradually throughout the stationary phase until the relative fluorescence unit reached the vertex (Fig. 2a). In parallel, the intracellular proteins that were sampled in a time course were determined by SDSPAGE analysis. The data indicated that the expression of GFP quantitatively was accumulated $9 \mathrm{~h}$ after fermentation, before which there were few GFP proteins that were scarcely detected on the PAGE (Fig. 2b). These results indicate that the transcription of $\mathrm{P}_{\text {srfa }}$ occurs in the late growth phase, whereas the activity of the promoter is inhibited in the early stage of cell-growth, permitting celldensity-dependent expression. The cell-density-dependent transcription of $\mathrm{P}_{\text {srfa }}$ is subjected to simple regulated mechanism of the ComA-ComP phosphorylation cascade compared to that of the recently reported gene expression system, by which the $P_{\operatorname{manP}}$ is involved in a rather complex regulatory network, making it necessary to delete the $\operatorname{man} P$ gene in the operon to achieve self-inducible 


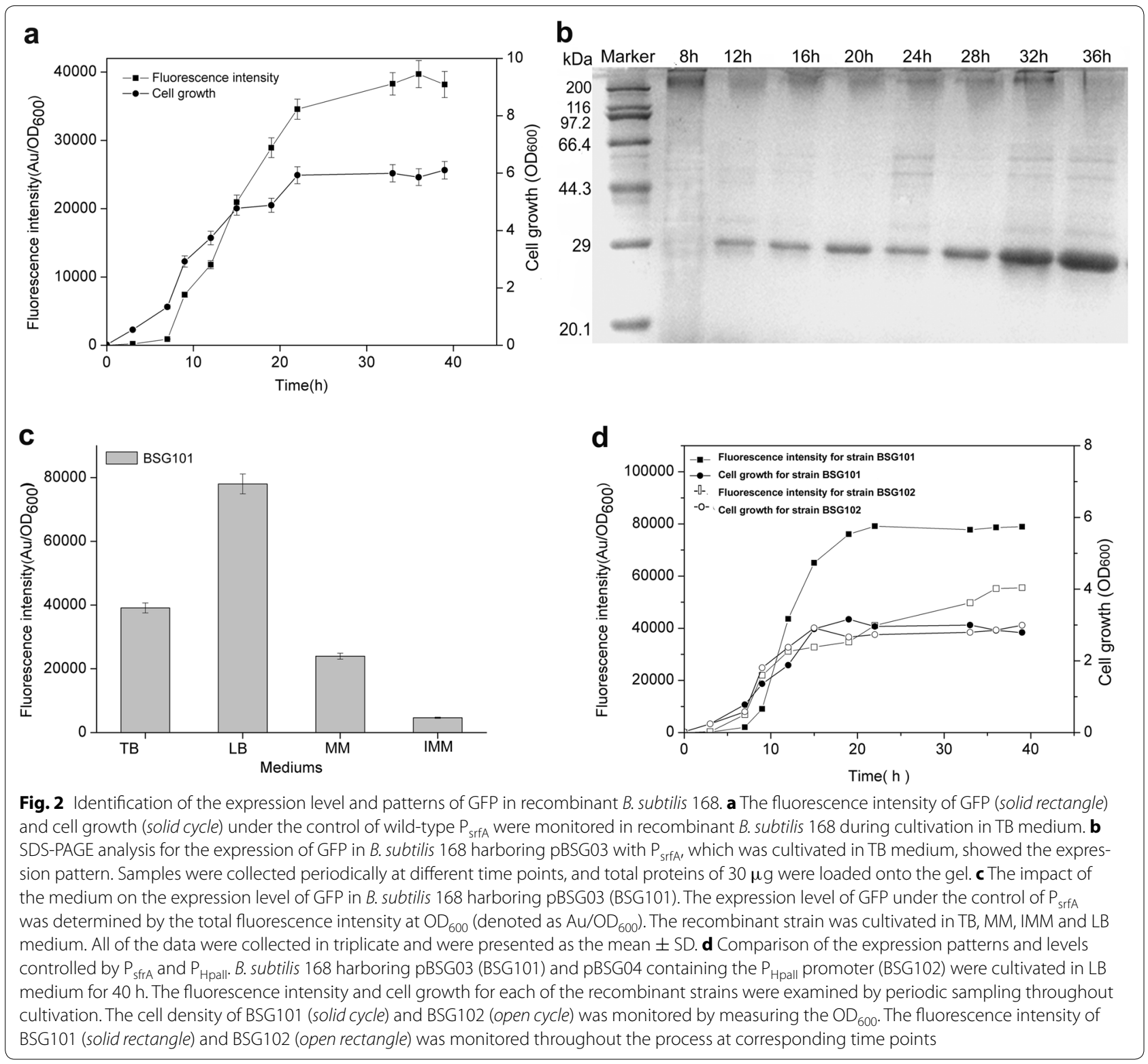

expression properties. Otherwise, the gene expression under $\mathrm{P}_{\operatorname{manP}}$ is typically mannose-inducible in wild-type B. subtilis [16].

Meanwhile, the effect of four different culture media (TB medium, MM medium, IMM medium and LB medium) on $\mathrm{P}_{\text {srfA }}$-mediated GFP expression in B. subtilis 168 (BSG101) was estimated in the following experiments. The data of the fluorescence intensity showed that the recombinant strain grown in LB medium achieved the maximal expression level, in which the expression level of GFP was approximately twofold higher than that in TB medium (Fig. 2c).

$\mathrm{P}_{\text {HpaII }}$ is a strong constitutive promoter, has comparable expression strength to that of $\mathrm{P}_{43}$, and has been used to construct an array of vectors for the over-production of recombinant proteins [22, 23]. To contrast the transcriptional level of $\mathrm{P}_{\text {srfA }}$ with that of $\mathrm{P}_{\text {HpaII }}$, plasmid pBSG04 harboring the $\mathrm{P}_{\mathrm{HpaII}}-\mathrm{GFP}$ expression cassette was constructed and transformed into $B$. subtilis 168, generating BSG102. Over the $40 \mathrm{~h}$ of fermentation in LB medium, each culture of the two recombinant strains was sampled periodically to measure the expression level. The data showed that the overall expression of GFP in BSG101 was higher than that of BSG102 by 1.5fold (Fig. 2d), even though the final biomasses of the two strains were nearly the same. These results indicate that the $\mathrm{P}_{\text {srfA }}$ is a potentially strong promoter for gene expression in B. subtilis. 


\section{Expression pattern of GFP in markerless deletion mutant and the protease-deficient mutants}

Based on the organization of the $s r f$ operon, the native $\mathrm{P}_{\text {srfa }}$ would also be activated, resulting in the expression of genes in the operon. To ascertain whether the background activation of the srf operon occurred simultaneously with heterologous gene expression, the markerless deletion mutant BSG1681 was constructed by completely deleting the full-length of $\mathrm{P}_{\text {srfa }}$ on the chromosome.

To compare the transcriptional features and expression levels of $\mathrm{P}_{\text {srfA }}$ in BSG1681 with the other three types of hosts (wild-type 168, B. subtilis WB600 and WB800), plasmid pBSG03 was introduced into the above hosts, generating BSG103, BSG101, BSG104, and BSG105, respectively. The levels of fluorescence intensity were monitored in the four recombinant strains throughout culturing. As expected, the transcriptional feature of $\mathrm{P}_{\text {srfa }}$ in BSG103 was similar to that in BSG101, BSG104 and BSG105, giving a transcription pattern of cell-densitydependent auto-regulation. Noticeably, the final fluorescence intensity in BSG101, BSG103 and BSG105 was similar, but slightly higher than that in BSG104 (Fig. 3ad). These results suggest that $P_{\text {srfa }}$ has a broad transcriptional compatibility with the cell-density-dependent pattern in various hosts. The final expression levels of GFP in the four different hosts were analyzed by SDSPAGE, and the data were consistent with those of the fluorescence intensity (Fig. 3e).

\section{Enhancement of the expression level by engineering the consensus sequence within the srfA promoter}

Although the cell-density-dependent expression system was characterized as highly transcribed and broadly compatible in various $B$. subtilis hosts, the duration of exponential expression under the control of the wildtype promoter was short, scarcely $10 \mathrm{~h}$ (Fig. 3a-d). The exponential expression phase in the other constructed auto-regulation systems starts at approximately the midexponential growth phase and terminated during the beginning of the stationary phase [24]. In addition, the activity of the wild-type promoter (e.g., cry3Aa), which behaves in a cell-density-dependent manner, usually disallows the over-production of a large amount of heterologous proteins to the desired level. Thus, engineering the promoters for higher capacity is the major demand for augmenting the over-production of heterologous proteins [9].

As one of the most efficient and prevalent strategies, promoter engineering has been widely used to tune the gene expression level, both for high levels of protein expression and tunable gene expression in synthetic biology $[25,26]$. The major essential elements in prokaryotic promoters that mainly determine their overall transcriptional activity are the -10 and -35 consensuses motifs, while other factors, such as the gene context, could also influence transcriptional activity [27]. This feature indicates that the two motifs are potential targets to be engineered within the promoter sequence. In this study, to enhance the activity of $\mathrm{P}_{\text {srfa }}$, the sequence of the -10 and -35 motifs in $P_{\text {srfa }}$ was compared with the $\sigma^{\mathrm{A}}$-dependent consensuses in $B$. subtilis. The alignment showed that the two motifs in $\mathrm{P}_{\text {srfa }}$ were in poor homology to the consensus. Therefore, the consensus -10 (TATAAT) and -35 (TTGACT) motifs of $\sigma^{\mathrm{A}}$-dependent promoters substituted for the -10 (TAAACT) and -35 (GTGATA) motifs of the $\mathrm{P}_{\text {srfA }}$ in plasmid pBSG03, resulting in plasmid pBSG05. After transforming pBSG05 into B. subtilis 168 (generating BSG106), the cell growth and fluorescence intensity were monitored throughout culturing. After $20 \mathrm{~h}$ of culture, the fluorescence intensity peaked, and thereafter, the maximal level did not decrease until $80 \mathrm{~h}$ of culture. The maximal expression level under the control of engineered $\mathrm{P}_{\text {srfa }}$ was approximately twofold stronger than that of the wild-type promoter (Fig. 4), demonstrating that engineering the poorly conserved -10 and -35 motifs within the promoters lead to fold increases of the transcriptional level. Despite engineering the non-inducible promoters, a set of other promoters, including inducible promoters, has been engineered to achieve a stronger over-production level through this strategy $[15,28]$.

\section{Development of the cell-density-dependent expression system to an auto-regulatory system}

The aforementioned expression system displayed a celldensity-dependent expression pattern. However, the cell density did not achieve a higher level than expected. According to the data referring to the expression pattern, we proposed that the initiation of a high expression level overlapped the rapid growth stage, leading to competition for energy and chemicals. Therefore, to achieve a high cell density and the desired over-production, expression initiation should be retarded until the cell density reaches a high level, avoiding mutual intervention between the two biological events. Nutrients that delayed expression while promoting cell growth were regarded as prospective candidates. A previous study revealed that the addition of glucose to the growth medium inhibits the expression of many genes, including srf operon [29].

Thus, various concentrations of glucose were chosen to appraise the influence of glucose on the expression pattern, cell biomass and expression levels. First, the cell growth, fluorescence intensity and glucose consumption rate were measured with the addition of $1,1.5,2$, and $2.5 \%$ concentrations of glucose. The addition of all of the concentration of glucose, except for $2.5 \%$, elevated 


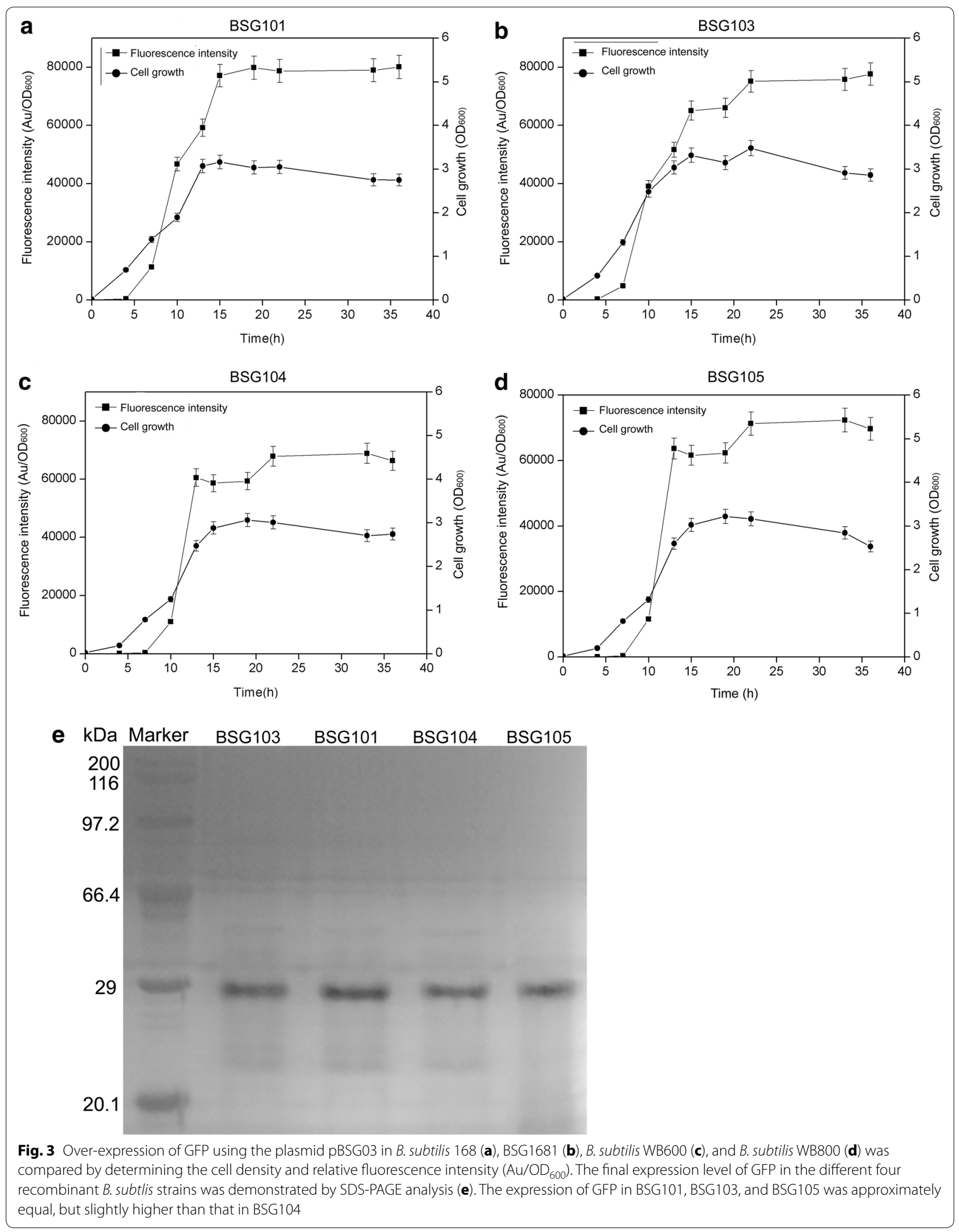




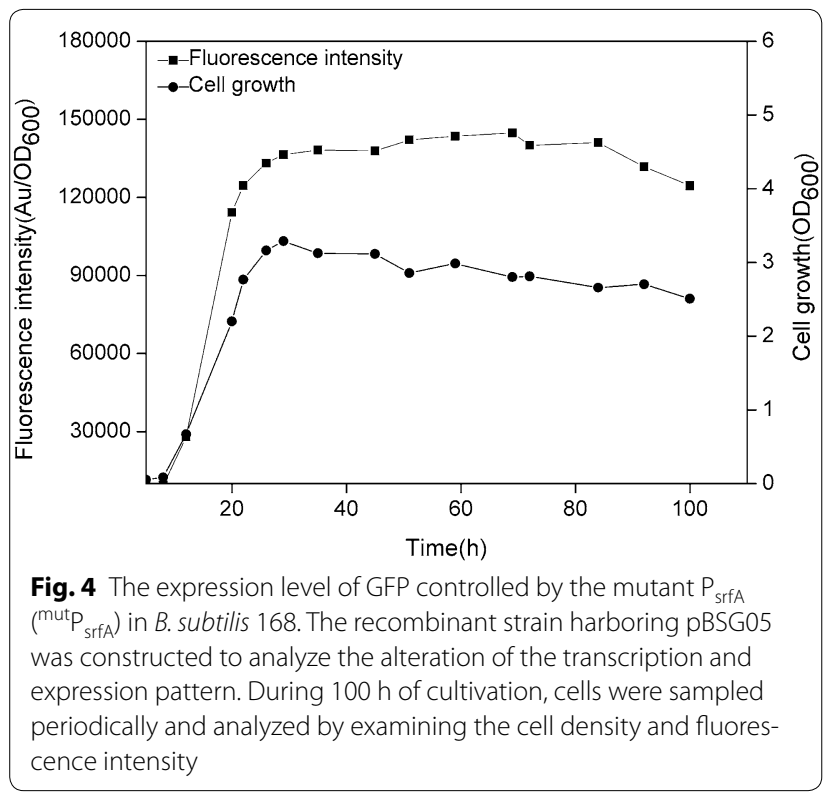

the final cell-density in the BSG101 strain; the addition of $1.5 \%$ glucose led to the highest cell density, which was nearly threefold higher than that of the glucose-free culture (Fig. 5a). The $1.5 \%$ glucose in the medium was depleted after $16 \mathrm{~h}$, at which time the 2 and $2.5 \%$ glucose remained in the medium (Fig. 5b). GFP expression sharply increased in the $1,1.5$, and $2 \%$ glucose groups when glucose was depleted, before which GFP was significantly inhibited (Fig. 5c). Among the four groups, the highest expression level of GFP was acquired by the addition of $1.5 \%$ glucose. The highest expression level was more than 2.5 -fold higher than that of glucose-free cultivation (Fig. 5c), indicating that the addition of glucose not only augment the expression level of heterologous genes but also give the system an auto-regulatory expression pattern. Interestingly, the addition of $2.5 \%$ glucose completely inhibited expression throughout cultivation (Fig. 5c). Then, the expression of GFP in BSG106 was examined to determine the effect of $1.5 \%$ glucose on the expression level of GFP under the engineered $P_{\text {srfa }}$ $\left({ }^{\text {mut }} \mathrm{P}_{\text {srfA }}\right)$. As expected, the expression of GFP initiated after the $1.5 \%$ glucose was depleted and maintained at the maximal level from $40 \mathrm{~h}$ until the end of cultivation (Fig. 5d). The maximal expression level under the control of ${ }^{\text {mut }} \mathrm{P}_{\text {srfa }}$ was approximately fourfold higher than that of the wild-type promoter $\mathrm{P}_{\text {srfa }}$ without adding of $1.5 \%$ glucose (Fig. 2d). Moreover, the total amount of GFP was determined by measuring the average fluorescence intensity (as calculated by arbitrary units per milliliter of culture) and by SDS-PAGE analysis. The highest fluorescence intensity and accumulative GFP protein were obtained under the control of ${ }^{\mathrm{mut}} \mathrm{P}_{\text {srfa }}$ with the addition of $1.5 \%$ glucose (Fig. 5e).
Taken together, the cell-density-dependent system that is mediated by $\mathrm{P}_{\text {srfa }}$ could be contrived to be an auto-regulatory device by the regulatory effect of glucose repression. This simple method eventually achieves a high cell density without a complex gene deletion or modification of the genome in the host. Regarding other developed auto-inducible expression systems, certain genes that are involved in the regulatory network should be disrupted or deleted to make an auto-inducible expression system while preventing native gene expression from interfering with the heterologous transcription that is mediated by the used promoters. Generally, B. subtilis under the control of $\mathrm{P}_{\operatorname{manP}}$, which is intrinsically a mannose-induced system, has been successfully fabricated to an autoinducible expression by the deletion of the $\operatorname{man} P$ gene in the PTS pathway [16].

\section{Over-production of AP using the auto-regulatory gene expression system}

To estimate the suitability of the system for the over-production of the heterologous protein, AP from B. subtilis Zj016, plasmid pBSG06 was constructed under the control of promoter ${ }^{\text {mut }} \mathrm{P}_{\text {sffA }}$. A previous report demonstrated the expression level of AP in B. subtilis WB600 under the control of $\mathrm{P}_{\mathrm{HpaII}}$. However, the expression and secretion levels were incomparable to those of other proteins [22, 30, 31]. Plasmid pBSG06 was introduced into B. subtilis 168 , generating recombinant strain BSG107. The culture procedure was similar to that for the auto-regulatory expression mentioned above. The cell growth, AP activity, and protein over-production were measured throughout cultivation. As expected, AP expression displayed the auto-regulatory pattern coupled with a cell-densitydependent manner. The highest activity of AP that was obtained was $87.89 \mathrm{U} / \mathrm{mL}$, and the cell-density at $\mathrm{OD}_{600}$ achieved a level of approximately 7.87 (Fig. 6a). The expression property also be verified at the protein level by SDS-PAGE analysis (Fig. 6b). Those results indicate that ${ }^{\text {mut }} \mathrm{P}_{\text {srfa }}$-mediated system could be used to express heterologous proteins in B. subtilis.

\section{Conclusions}

In this study, a novel auto-regulatory gene expression system coupled to cell density in B. subtilis was constructed and developed using the $\operatorname{srfA}$ promoter that is associated with triggering quorum sensing. Using the expression system, expression was separated by the cell growth phase and high expression phase, during which the addition of glucose not only augmented the two-phase expression profile and enabled auto-regulation but also increased the final cell density. In addition, the expression strength was remarkably enhanced by engineering the -10 and -35 region via substitution to the highly 

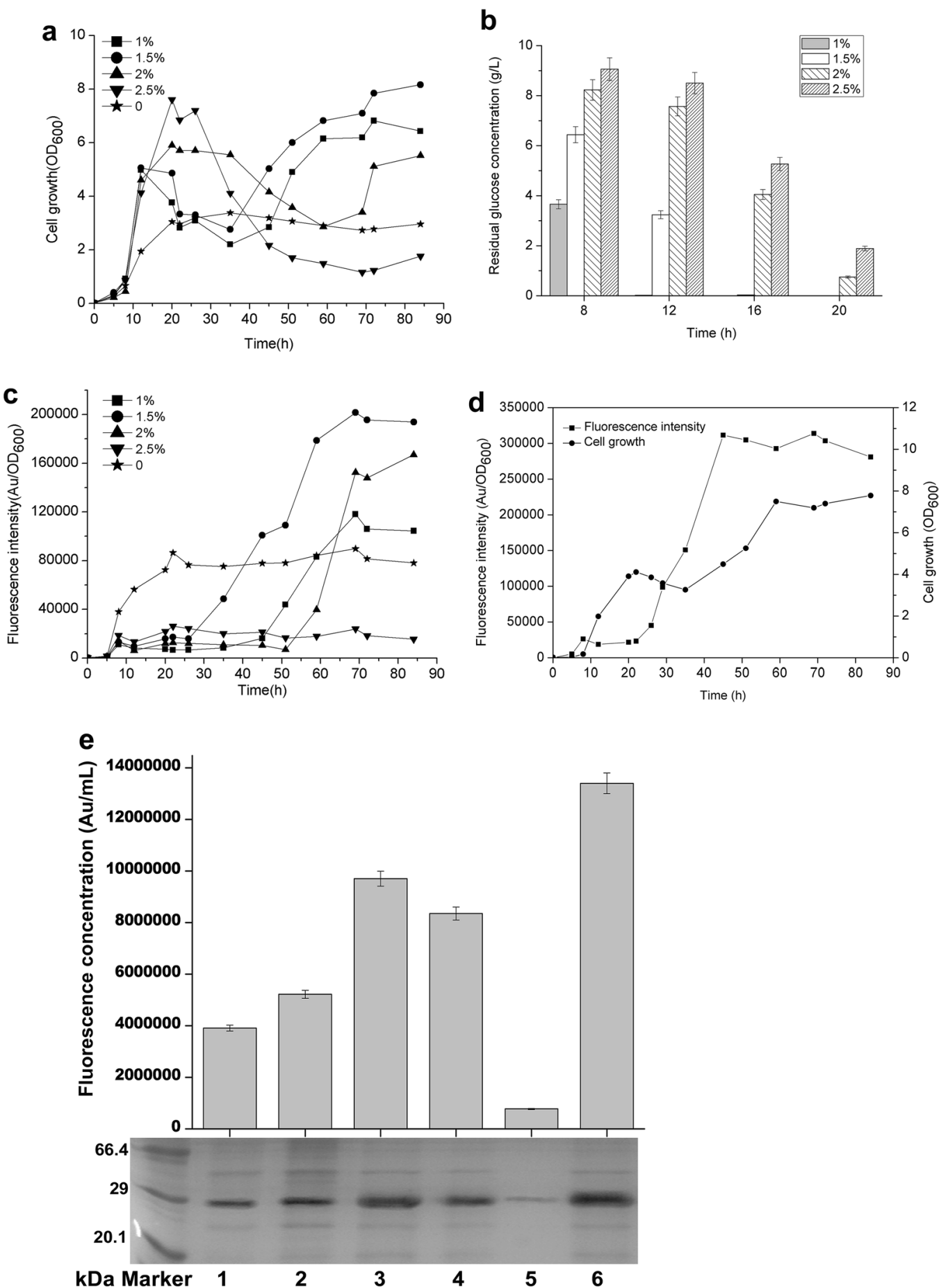

Fig. 5 The effect of different concentrations of glucose on the $P_{\text {srfA }}$ and ${ }^{\text {mut }} P_{\text {sffA }}$-controlled expression of GFP. a The cell density profiles for BSG101 harboring wild-type $\mathrm{P}_{\text {srfa }}$ in LB medium with the addition of $1 \%$ (solid rectangle), $1.5 \%$ (solid cycle), $2 \%$ (solid triangle), and $2.5 \%$ (solid inverse triangle) glucose. Medium without the addition of glucose was used as the control group (solid pentangle). b Glucose consumption profiles at 8, 12, 16, and $20 \mathrm{~h}$ with different initial concentrations. cThe fluorescence intensity profiles that were detected in BSG101 with different concentrations of glucose corresponded to those in $\mathbf{a}$. d The fluorescence intensity and the cell density that were detected in recombinant strain BSG106 that harbored ${ }^{\text {mut }} P_{\text {sff }}$ in which the intrinsic sequences of -10 and -35 were replaced by the corresponding conserved sequences for $\sigma^{\mathrm{A}}$-dependent promoters. e Comparison of the highest fluorescence intensity and the corresponding GFP expression level with or without the addition of glucose in B. subtilis 168 under the control of wild-type $P_{\text {sffA }}$ and ${ }^{\text {mut }} P_{\text {sffA. }}$. Sample 1 represents the BSG101 without the addition of glucose, which was designated as the control. Samples 2-5 represent strain BSG101 with the addition of 1, 1.5, 2, and 2.5\% glucose, respectively. Sample 6 represents strain BSG106 (harboring ${ }^{\text {mut }} \mathrm{P}_{\text {srf }}$ ) with the addition of $1.5 \%$ glucose. All of the experiments were independently performed in triplicate 

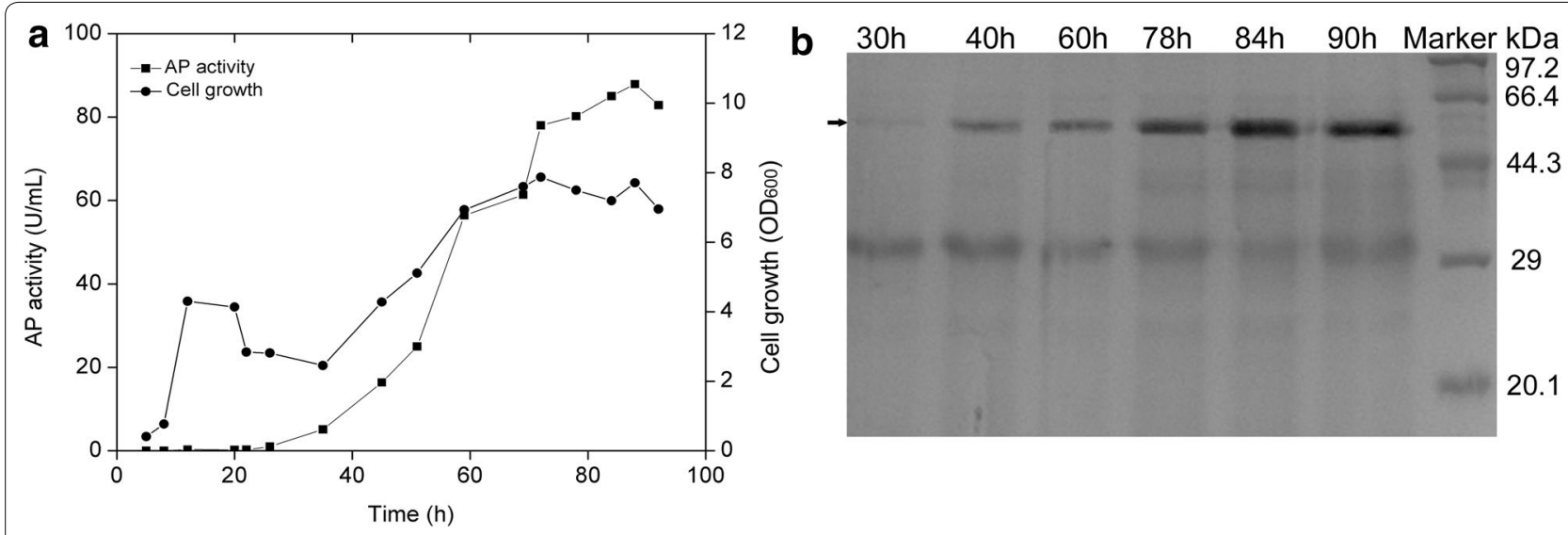

Fig. 6 Over-production of aminopeptidase (AP) using the constructed auto-regulatory gene expression system. Plasmid pBSG06 harboring the signal peptide $\left(\mathrm{SP}_{\mathrm{ap}}\right)$ and $\mathrm{AP}$ downstream of the mut $\mathrm{P}_{\text {sffA }}$ was introduced into B. subtilis 168 . The recombinant strain BSG107 was then cultured in LB medium for more than $40 \mathrm{~h}$ with periodical sampling. a The activities of AP in the supernatant (solid rectangle) and cell density (solid cycle), as determined at different times, displayed an AP over-production pattern that was related to cell growth. b The expression of AP was analyzed by SDS-PAGE. The position of the AP protein bands corresponding to 30,40,60,78, 84, and $90 \mathrm{~h}$ is marked with a black arrow

conserved sequences. Furthermore, aminopeptidase was successfully over-produced as the test protein using the newly constructed gene expression system, achieving a 1.7-fold over-expression level compared to that under the control of the generally regarded strong promoter $\mathrm{P}_{\mathrm{HpaII}}$ [30]. These features of the auto-regulatory gene expression system give the system great potential for the overproduction of enormous high-value-added proteins at the industrial scale.

\section{Methods}

\section{Strains, plasmids and growth conditions}

The bacterial strains and plasmids that were used in this study are listed in Table 1. E. coli JM109 was used as a host for gene cloning. B. subtilis 168 and engineered B. subtilis BSG1681 were used for the gene expression and gene integration experiments. The media used in this study were glucose minimal medium (MM) [32], improved minimal medium (IMM, adding $0.02 \%$ Casamino acids to MM medium), Luria-Bertani medium (LB), and TB. All of the strains were cultured in the appropriate medium with aeration at $37{ }^{\circ} \mathrm{C}$. When appropriate, B. subtilis growth media was supplemented with kanamycin $(5 \mu \mathrm{g} / \mathrm{mL})$ and $E$. coli growth media with ampicillin $(10 \mu \mathrm{g} / \mathrm{mL})$. The cell density was determined by measuring the $\mathrm{OD}_{600}$ with a UV-1800/PC spectrophotometer (Shanghai, MAPADA Instrument Co., Ltd., China).

\section{Recombinant DNA techniques}

Plasmid construction was performed in E. coli, and extraction was processed following the standard procedure as previously described [33]. Recombinant plasmids were transformed into $B$. subtilis as previously described
[30]. Enzymes were obtained from TOYOBO (Osaka, Japan), TaKaRa (Dalian, China), or New England Biolabs (Beijing, China) and were used according to the manufactures' protocols. The primers used in this study are listed in Table 2. PCR was performed using KOD DNA polymerase (Osaka, Japan). All of the recombinant plasmids that were constructed in this work were confirmed by DNA sequencing (Shanghai Sangon Biotech Co., Ltd., China).

\section{Construction of plasmids and mutant strains with markerless gene deletion}

Plasmid construction was carried out using the Sequence and Ligation Independent Cloning (SLIC) method, with few modifications [34]. The primers that were used to amplify the donor sequence were designed to have 30-bp flanking regions that are homologous to the receptor plasmid insertion regions, and the receptor plasmid was linearized by inverse PCR. The main procedures used for construction are shown in Fig. 7. The plasmids constructed in this study were E. coli-B. subtilis shuttle vectors.

To construct pBSG01, Fragment 1, which is $2.2 \mathrm{~kb}$ and comprises the ampicillin resistance gene (bla) and replication region (pBR322 ori) and was flanked by the corresponding homology to Fragment 2, was amplified from pUC19 with primers P1 and P2. Concomitantly, Fragment 2 carrying the replication protein (Rep), kanamycin resistance gene $\left(n e o^{r}\right)$, and bleomycin resistance gene (ble), which was flanked by the corresponding homology of Fragment 1, was amplified from plasmid pMA09 using primers P3 and P4. These two fragments were mixed at the molar ratio of 1:2 prior to treatment with T4 DNA polymerase. After a 2.5 -min treatment, the mixture was 
Table 1 Strains and plasmids used in this study

\begin{tabular}{|c|c|c|}
\hline $\begin{array}{l}\text { Strains and } \\
\text { plasmids }\end{array}$ & Relevant properties & References \\
\hline \multicolumn{3}{|l|}{ Strains } \\
\hline E. coli JM109 & 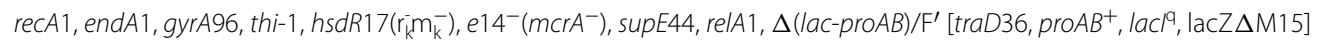 & \\
\hline \multicolumn{3}{|l|}{ B. subtilis } \\
\hline 168 & $\operatorname{trpC2}$ & \\
\hline WB600 & (168) $\Delta n p r E, \Delta$ aprA, $\Delta e p r, \Delta$ bpr, $\Delta m p r, \Delta n p r B$ & {$[40]$} \\
\hline WB800 & (168) $\Delta n p r E, \Delta a p r A, \Delta e p r, \Delta b p r, \Delta m p r, \Delta n p r B, \Delta v p r, \Delta w p r A$ & {$[41]$} \\
\hline BSG1681 & $(168) \Delta P_{\text {srfa }}$ & This study \\
\hline BSG101 & $168, \mathrm{pBSG} 03\left(\mathrm{P}_{\text {srfa }}-g f p\right)$ & This study \\
\hline BSG102 & 168, pBSG04 (P $\left.\mathrm{Hpall}^{-g f p}\right)$ & This study \\
\hline BSG103 & BSG1681, pBSG03 ( $\left.P_{\text {srfA }}-g f p\right)$ & This study \\
\hline BSG104 & WB600, pBSG03 ( $\left.P_{\text {sffA }}-g f p\right)$ & This study \\
\hline BSG105 & WB800, pBSG03 (P $\left.P_{\text {srfa }}-g f p\right)$ & This study \\
\hline BSG106 & 168, pBSG05 $\left({ }^{\text {mut }} P_{\text {srfa }}-g f p\right)^{a}$ & This study \\
\hline BSG107 & $168, \mathrm{pBSG} 06\left({ }^{\text {mut }} \mathrm{P}_{\text {srfa }}-a p\right)$ & This study \\
\hline \multicolumn{3}{|l|}{ Plasmids } \\
\hline P7Z6 & zeor bla Cre/lox & {$[38]$} \\
\hline pUC19 & pUC origin $\mathrm{P}_{l a c} A p^{r}$ & TaKaRa \\
\hline pMA09 & E. coli-B. subtilis shuttle vector, $A p^{r} K a n^{r} P_{\text {Hpall }}$ & {$[30]$} \\
\hline pMA05 & E. coli-B. subtilis shuttle vector, $A p^{r}, K_{a n}^{r}, P_{\text {Hpall }}-A P$ & {$[30]$} \\
\hline pBSG01 & blar, neo ${ }^{r}$, E. coli-B. subtilis shuttle vector & This work \\
\hline pBSG02 & pBSG01 ligated with $P_{\text {srfa }}$ & This study \\
\hline pBSG03 & pBSG02 with GFP ligated downstream of $P_{\text {srfA }}$ & This study \\
\hline pBSG04 & pBSG03 with $P_{\text {srfa }}$ replaced by $P_{\text {Hpall }}$ & This study \\
\hline pBSG05 & pBSG03 with ${ }^{\text {mutp }} P_{\text {srfa }}$ & This study \\
\hline pBSG06 & pBSG02 with AP ligated downstream of ${ }^{\text {mut }} P_{\text {srfa }}$ & This study \\
\hline
\end{tabular}

incubated on ice for $10 \mathrm{~min}$, allowing for the two fragments to be annealed, after which the mixture was transformed to E. coli JM109 competent cells [35]. The resulting plasmid was termed pBSG01.

To introduce promoter $\mathrm{P}_{\text {srfA }}$ into the plasmid pBSG01, the $0.6-k b P_{\text {srfa }}$ flanked by a 30-bp homology sequence upstream and downstream of the inserted position in pBSG01 was amplified from the chromosome of $B$. subtilis 168 using primers P5 and P6. Plasmid pBSG01 was then linearized using inverse PCR with primers P7 and P8. The two fragments were joined according to the steps described above. The resulting plasmid was termed pBSG02. To insert GFP downstream of $\mathrm{P}_{\text {srfa }}$ in pBSG02, the $g f p$ gene was amplified from $\mathrm{pBS} 1154$ with primers $\mathrm{P} 9$ and P10, flanked by the 30-bp homology sequence corresponding to the upstream and downstream sequences at the inserted position. Meanwhile, pBSG02 was linearized by inverse PCR with primers P11 and P2. These two fragments were joined by the SLIC method mentioned above, generating plasmid pBSG03 for expression in B. subtilis. To construct the comparative plasmid pBSG04 under the control of promoter HpaII $\left(\mathrm{P}_{\text {HpaII }}\right), \mathrm{P}_{\text {HpaII }}$ was inserted into pBSG03 by replacing $\mathrm{P}_{\text {srfA }}$ using mega-primer PCR with a whole plasmid protocol using primers P7 and P12 [36]. Plasmid pBSG05, harboring the mutant $\mathrm{P}_{\text {srfA }}$, was constructed with primers P13 and P14 using pBSG03 as the template through inverse PCR. Then, the endonuclease $D p n I$ was used to cut the template plasmid. To express aminopeptidase (AP) under the control of $\mathrm{P}_{\text {srfA }}$, plasmid pMA05 was used as the template to amplify AP with primers P15 and P16, and pBSG02 was linearized with primers P11 and P2. Plasmid pBSG06 was obtained by processing these two fragments in the same manner as for pBSG02. All of the plasmid constructs were verified by DNA sequencing.

The markerless deletion of genes on the chromosome of B. subtilis 168 was performed as previously described, with some modification $[37,38]$. The sequences of the $B$. subtilis dif site (dif ${ }_{\text {B. subtilis: ACTTCCTAGAATATATAT- }}$ TATGTAAACT) were used in this study.

To delete the promoter region in the srf operon from the $B$. subtilis 168 chromosome, two tripartite fragments 
Table 2 Oligonucleotides used in this study

\begin{tabular}{|c|c|}
\hline Primers & Sequences $^{\mathbf{a}}$ \\
\hline P1 & CTCTTCCGCTTCCTCGCTCACTGACTCGC \\
\hline P2 & GCGGTATTTTCTCCTTACGCATCTGTGCGG \\
\hline P3 & $\underline{\text { GCGAGTCAGTGAGCGAGGAAGCGGAAGAGTAGAAGAAGCTTGGAGACAAGGTAAAGG }}$ \\
\hline P4 & CCGCACAGATGCGTAAGGAGAAAATACCGCCATATGTAAATCGCTCCTTTTTAGGTGGCAC \\
\hline P5 & CCCCCTTTGCTGAGGTGGCAGAGGGCAGGTATCGACAAAAATGTCATGAA \\
\hline P6 & $\underline{\text { CCGCACAGATGCGTAAGGAGAAAATACCGCCATTGTCATACCTCCCCTAATCTTTATAAG }}$ \\
\hline P7 & ACCTGCCCTCTGCCACCTCAGC \\
\hline P8 & GCGGTATTTTCTCCTTACGCATC \\
\hline P9 & $\underline{\text { CTTATAAAGATTAGGGGAGGTATGACAATGATGAGTAAAGGAGAAGAACTTTTCACTGGAG }}$ \\
\hline P10 & CCGCACAGATGCGTAAGGAGAAAATACCGCTTATTTGTATAGTTCATCCATG \\
\hline P11 & CATTGTCATACCTCCCCTAATC \\
\hline P12 & ATGAGTAAAGGAGAAGAACT \\
\hline P13 & $\underline{\text { ACTTTTCACCCATTITTCGGTTGACAAAACATTTTTTTTCATTTATAATGAACGGTAGAAAGATAAAAAATATTGAAA }}$ \\
\hline P14 & ITTTATCTTTCTACCGTTCATTATAAATGAAAAAAATGTTTTGTCAACCGAAAAATGGGTGAAAAGTTTCATGCGGG \\
\hline P15 & 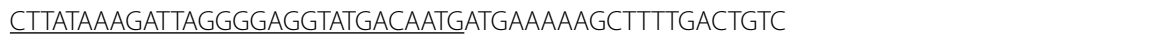 \\
\hline P16 & $\underline{\text { CCGCACAGATGCGTAAGGAGAAAATACCGCTTATTTGATATCTTCAAAAATG }}$ \\
\hline P17 & CGCAGATGTAGTCAACACCGAGTGCGTC \\
\hline P18 & ATCAAGAGTTTACATAATATATATTCTAGGAAGTATCAATCAATTCCATATAGCCTTTCCC \\
\hline P19 & ACTGAACTTCCTAGAATATATATTATGTAAACTATGGAAATAACTTTTTACCCTTTAACGG \\
\hline P20 & ATCGTTGATTAGGAGATTATACGG \\
\hline P21 & TTGATACTTCCTAGAATATATATTATGTAAACTCTTGATATGGCTTTTTATATGTG \\
\hline P22 & TCCATAGTTTACATAATATATATTCTAGGAAGTTCAGTCCTGCTCCTCGGCCACG \\
\hline
\end{tabular}

${ }^{a}$ Homologous sequences were underlined, and dif ${ }_{B \text {. subtilis }}$ sequence was shown in bold

(Fig. 8) were amplified from the B. subtilis genome using the primers that are listed in Table 2. The specific procedure is described as follows. The up-sequence, which consisted of the approximately 1-kb homologous fragment upstream of $\mathrm{P}_{\text {srfA }}$, the dif ${ }_{\text {B. subtilis }}$ site, and 6-bp homologous region to the $5^{\prime}$ end of the gene zeo, was amplified by PCR with primers P17 and P18. Similarly, the down-sequence, which consisted of a 5-bp homologous fragment to the $3^{\prime}$ end of the gene $z e o$, the dif ${ }_{B}$. subtilis, and the approximately 1-kb homologous fragment downstream of the gene $\mathrm{P}_{\text {srfA }}$, was amplified with primers P19 and P20. Next, the zeocin resistance gene zeo was amplified from plasmid p7Z6 using primers P21 and P22, flanked by a 5-bp homology to the sequence in the chromosome followed by the 28-bp dif sequence at the $5^{\prime}$ terminus and the 28-bp dif sequence followed by a 5-bp homology to the chromosome. These three fragments were assembled by fusion PCR. The resulting $2.5-\mathrm{kb}$ fragment was then sequenced and transformed into the $B$. subtilis 168 competent cells. The integrants were selected on LB agar medium containing $25 \mu \mathrm{g} / \mathrm{mL}$ zeocin. The positive clones were selected before inoculating the LB broth in the absence of antibiotics and were incubated for approximately $36 \mathrm{~h}$ to produce zeocin-sensitive recombinant clones. Then, the culture was identified by replica agar plating with and without the selective antibiotic. Finally, the clones that grew on the agar plate in the absence of antibiotics were selected in liquid medium for identification by PCR using primers P17 and P20. The positive mutant strain that was deficient in $\mathrm{P}_{\text {srfa }}$ was named BSG1681 (B. subtilis 168: $\left.\Delta \mathrm{P}_{\text {srfA }}\right)$.

\section{GFP fluorescence assay}

A single colony of the appropriate $B$. subtilis strain picked on LB agar plates was inoculated in $5 \mathrm{~mL}$ of LB liquid medium and was cultured overnight for more than $12 \mathrm{~h}$ to serve as a preculture. Then, $0.6 \mathrm{~mL}$ of preculture was transferred into $250-\mathrm{mL}$ shaking flasks that were loaded with $30 \mathrm{~mL}$ of LB liquid medium to cultivate for 3 days, during which the culture medium was sampled every $2 \mathrm{~h}$. After cultivation, the cells were harvested by centrifugation, washed by PSB buffer $(50 \mathrm{mM}$ Tris- $\mathrm{HCl}, 100 \mathrm{mM}$ $\mathrm{NaCl}, \mathrm{pH}$ 7.5) for three times, and suspended in an appropriate diluted ratio. Then, a final volume of $200 \mu \mathrm{L}$ of the cell suspension was transferred to each well, and the fluorescence value (expressed as $\mathrm{Au}$ ) was recorded.

The fluorescent activity of GFP was monitored via fluorescence spectroscopy on a black flat 96-well plate using a Synergy ${ }^{\mathrm{TM}} \mathrm{H} 4$ multimode microplate reader (BioTek Instruments, Inc., USA). The excitation wavelength was 


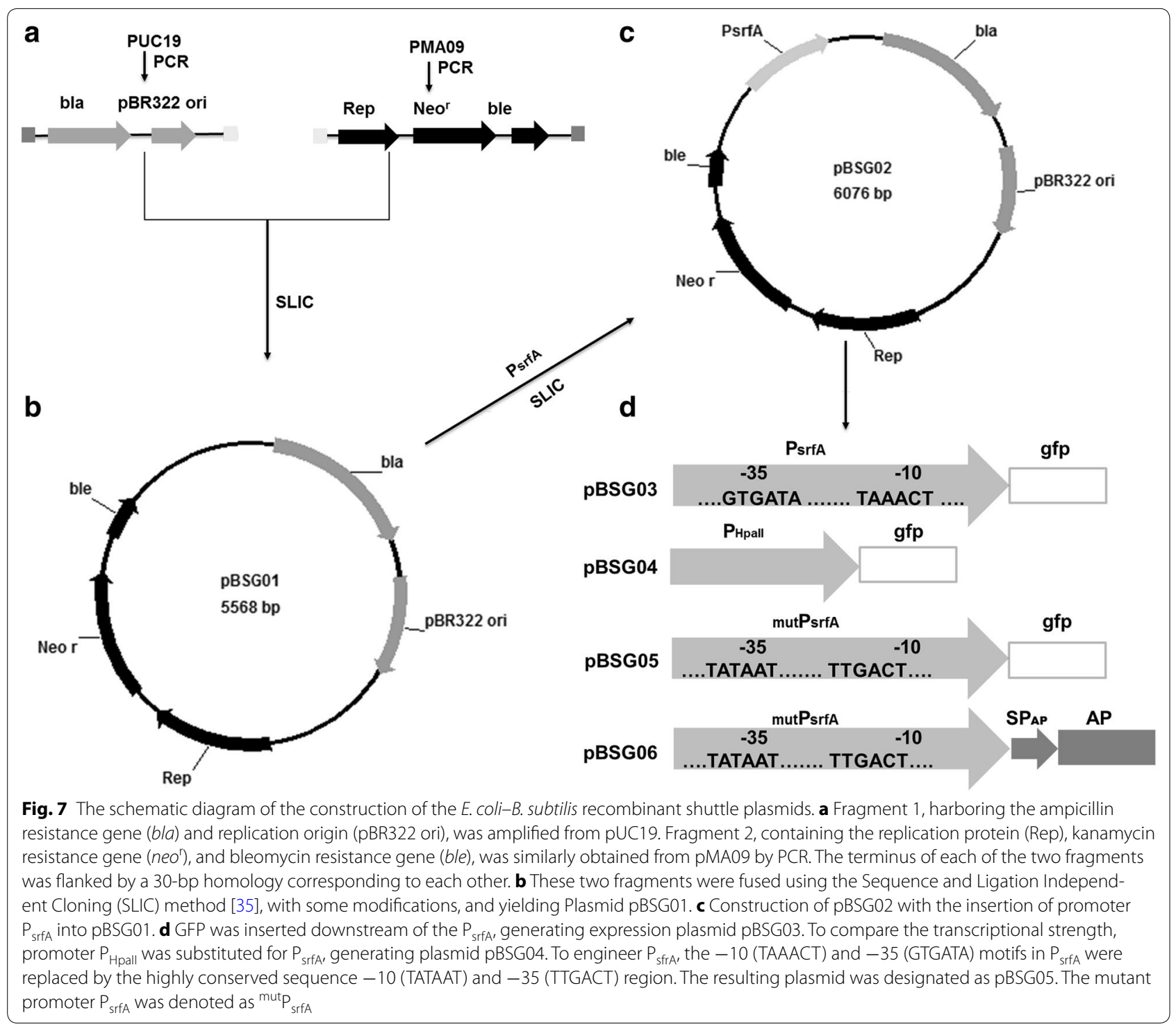

$495 / 9 \mathrm{~nm}$, and the emission wavelength was 525/9 nm with gain 80 . The determination of the GFP expression was calculated with the fluorescence intensity divided by the $\mathrm{OD}_{600}$ that was previously measured [39].

The relative fluorescence intensities which reflected the expression levels were calculated according to the method described by Toymentseva et al. [10]. The relative fluorescence intensity $\left(\mathrm{Au} / \mathrm{OD}_{600}\right)$ of three parallel samples of the recombinant B. subtilis strains harboring empty vector pBSG01 were averaged and subtracted from that of the recombinant strains harboring plasmids with GFP at the consistency time of cultivation. Growth was monitored by measuring the absorbance at $600 \mathrm{~nm}$. The data were averaged from three independent samples of the same time points.
Heterologous expression of aminopeptidase and enzyme activity analysis

A fresh overnight culture of the recombinant B. subtilis strain BSG107 harboring pBSG06 under the control of mutant $\mathrm{P}_{\text {srfA }}\left({ }^{\text {mut }} \mathrm{P}_{\text {srfA }}\right.$ ) was inoculated into $250-\mathrm{mL}$ shaking flasks that were loaded with $30 \mathrm{~mL}$ of LB liquid medium, the optical density of which was adjusted to $\mathrm{OD}_{600} 0.2$. Then, the culture was cultivated at $37^{\circ} \mathrm{C}$ with rigorous shaking for 2 days, and sampling was implemented throughout the fermentation process with an interval of $2 \mathrm{~h}$. Thereafter, crude AP in the fermentation supernatant was obtained by removing recombinant B. subtilis cells via centrifugation $(5 \mathrm{~min}, 10,000 \times g)$. AP activity was determined via a previously described method [23]. One unit of activity was defined as the 


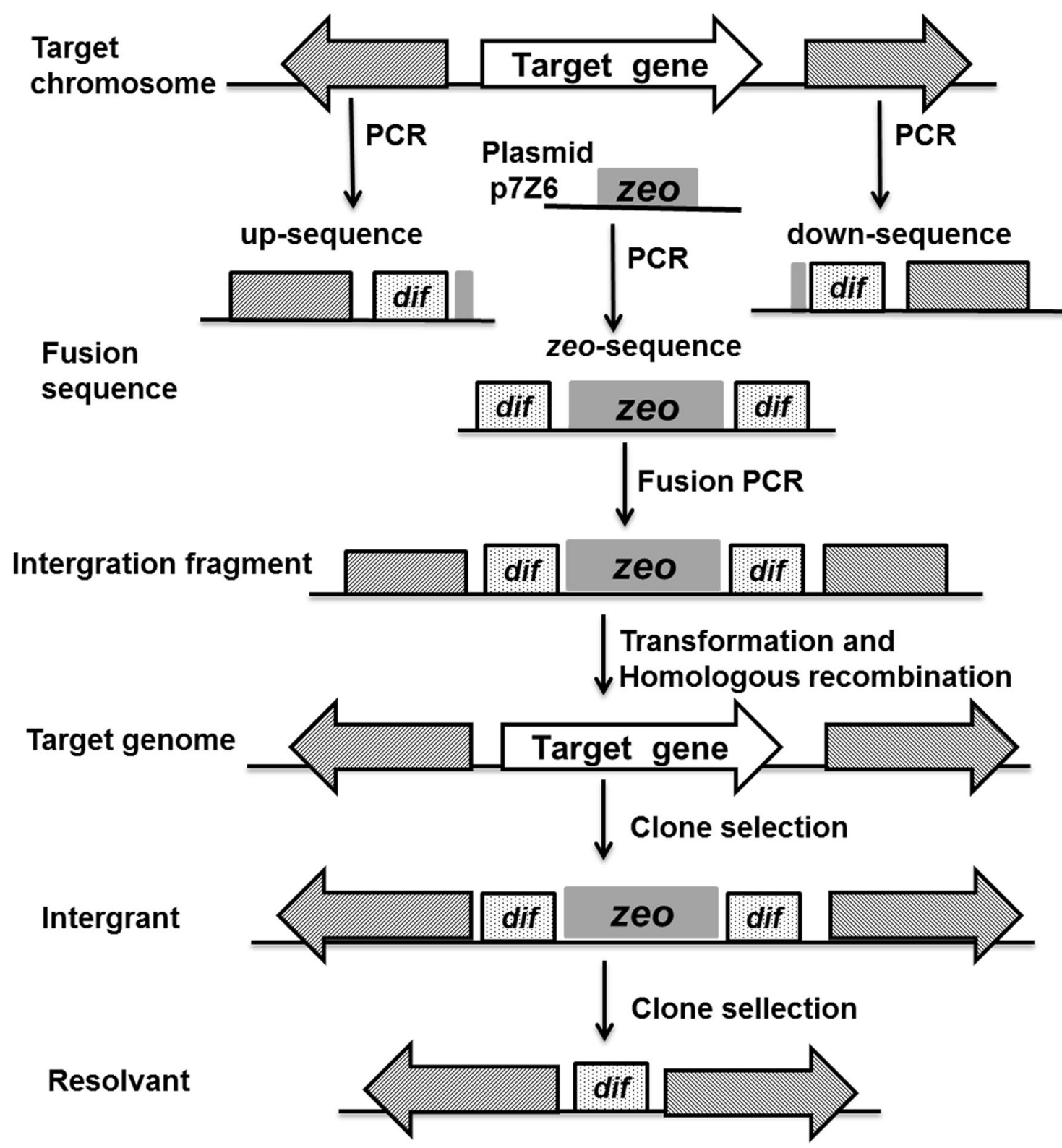

Fig. 8 The sketch displays the procedure for the deletion of the target gene on a chromosome using the dif/Xer recombination system. The shaded regions represented homology between the integration cassette and the genes flanking the target gene. zeo, the zeocin resistance gene zeo. The front (up-sequence) and back (down-sequence) regions flanking the target gene to be deleted were amplified from the chromosome of $B$. subtilis 168 , and the zeo sequence was cloned from plasmid p7Z6. These three fragments were joined by PCR; the resulting PCR products were transformed into B. subtilis 168, and zeor transformants were selected. After subculturing, Xer recombinants were selected

amount of enzyme that released $1 \mu \mathrm{mol} \mathrm{L}{ }^{-1} p$-nitroaniline $\min ^{-1}$ at $37{ }^{\circ} \mathrm{C}\left(\varepsilon_{405 \mathrm{~nm}}=9.98 \mathrm{~L} \mathrm{mmol}^{-1} \mathrm{~cm}^{-1}\right)$. The results are the averages of triplicate assays.

\section{Protein analysis and SDS-PAGE}

After cultivation for appropriate recombinant B. subtilis, the cells were harvested by centrifugation. The pelleted cells were then re-suspended in PBS buffer prior to disruption by ultra-sonication on ice. The crude cell extracts were separated by centrifugation, the supernatant was analyzed by SDS-PAGE according to the standard procedure, and the gels were subsequently stained by Coomassie brilliant blue R250 staining. The concentration of the total proteins was determined by the Bradford assay and equal amounts of total protein were loaded onto SDS-PAGE gels. 


\section{Abbreviations}

$\mathrm{P}_{\text {srfA }}$ : the promoter of the srf operon; PTS: phosphotransferase system; QS: quorum sensing; AP: aminopeptidase; GFP: green fluorescent protein; SLIC: sequence and ligation independent cloning; bla: ampicillin resistance gene; pBR322 ori: replication region; Rep: replication protein; neor ${ }^{r}$ kanamycin resistance gene; ble: bleomycin resistance gene; $\mathrm{P}_{\text {Hpall: }}$ : promoter of Hpall; $\mathrm{SP}_{\mathrm{ap}}$ : the signal peptide of aminopeptidase; ${ }^{\text {mut }} \mathrm{P}_{\text {srfA }}$ : the mutant of promoter $\mathrm{P}_{\text {srfA }}$.

\section{Authors' contributions}

CG constructed the plasmids, the variant strain, accomplished the determination of the recombinant expression system, analyzed the data and wrote the manuscript. WC conceived the idea, designed this study, analyzed the data and wrote the manuscript. $\mathrm{ZL}, J \mathrm{C}, J \mathrm{JG}, \mathrm{XH}$ were participated in the determination of expression pattern using GFP reporter gene. GX participated in the experiment of expressing aminopeptidase. ZZ conceived of the study, participated in its design, and coordination. All authors read and approved the final manuscript.

\section{Author details}

${ }^{1}$ School of Biotechnology, Key Laboratory of Industrial Biotechnology (Ministry of Education), Jiangnan University, 1800 Lihu Road, Wuxi, Jiangsu 214122, China. ${ }^{2}$ Wuxi Biortus Bioscience Co., Ltd, Wuxi, Jiangsu 214122, China.

\section{Acknowledgements}

The investigation was supported by a Project Funded by the Priority Academic Program Development of Jiangsu Higher Education Institutions, the 111 Project (No. 111-2-06), and the Jiangsu province "Collaborative Innovation Center for Advanced Industrial Fermentation" industry development program, the National High Technology Research and Development Program of China (863 Program, 2014AA021304), the Fundamental Research Funds for the Central Universities (JUSRP51411B), the National Natural Science Foundation of China (31400058), the Natural Science Foundation of Jiangsu Province (BK20130139), and the Public Project for Key Laboratory of Industrial Biotechnology, Ministry of Education (KLIB-KF201306).

\section{Compliance with ethical guidelines}

\section{Competing interests}

The authors declare that they have no competing interests.

Received: 17 June 2015 Accepted: 12 September 2015

Published online: 21 September 2015

\section{References}

1. Chen J, Gai Y, Fu G, Zhou W, Zhang D, Wen J. Enhanced extracellular production of alpha-amylase in Bacillus subtilis by optimization of regulatory elements and over-expression of PrsA lipoprotein. Biotechnol Lett. 2015;37(4):899-906.

2. Rabbani M, Mirmohammad Sadeghi H, Moazen F, Rahimi M, Salehi G. Cloning and expression of randomly mutated Bacillus subtilis alpha-amylase genes in HB101. Biotechnol Res Int. 2011. doi:10.4061/2011/305956.

3. Yang H, Liu L, Li J, Du G, Chen J. Heterologous expression, biochemical characterization, and overproduction of alkaline alpha-amylase from Bacillus alcalophilus in Bacillus subtilis. Microb Cell Fact. 2011;10:77.

4. Ying Q, Zhang C, Guo F, Wang S, Bie X, Lu F, et al. Secreted expression of a hyperthermophilic alpha-amylase gene from Thermococcus sp. HJ21 in Bacillus subtilis. J Mol Microbiol Biotechnol. 2012;22(6):392-8.

5. Lu Y, Lin Q, Wang J, Wu Y, Bao W, Lv F, et al. Overexpression and characterization in Bacillus subtilis of a positionally nonspecific lipase from Proteus vulgaris. J Ind Microbiol Biotechnol. 2010;37(9):919-25.

6. Zhang J, Kang Z, Ling Z, Cao W, Liu L, Wang M, et al. High-level extracellular production of alkaline polygalacturonate lyase in Bacillus subtilis with optimized regulatory elements. Bioresour Technol. 2013;146:543-8.

7. Chen PT, Shaw JF, Chao YP, David Ho TH, Yu SM. Construction of chromosomally located T7 expression system for production of heterologous secreted proteins in Bacillus subtilis. J Agric Food Chem. 2010;58(9):5392-9.
8. Wieland KP, Wieland B, Gotz F. A promoter-screening plasmid and xyloseinducible, glucose-repressible expression vectors for Staphylococcus carnosus. Gene. 1995;158(1):91-6.

9. Bongers RS, Veening JW, Van Wieringen M, Kuipers OP, Kleerebezem M. Development and characterization of a subtilin-regulated expression system in Bacillus subtilis: strict control of gene expression by addition of subtilin. Appl Environ Microbiol. 2005;71(12):8818-24.

10. Toymentseva AA, Schrecke K, Sharipova MR, Mascher T. The LIKE system, a novel protein expression toolbox for Bacillus subtilis based on the lial promoter. Microbial Cell Factories. 2012;11:143.

11. Bhavsar AP, Zhao X, Brown ED. Development and characterization of a xylose-dependent system for expression of cloned genes in Bacillus subtilis: conditional complementation of a teichoic acid mutant. Appl Environ Microbiol. 2001;67(1):403-10.

12. Phan TT, Nguyen HD, Schumann W. Novel plasmid-based expression vectors for intra- and extracellular production of recombinant proteins in Bacillus subtilis. Protein Expr Purif. 2006;46(2):189-95.

13. Le Thuy AT, Schumann W. A novel cold-inducible expression system for Bacillus subtilis. Protein Expr Purif. 2007;53(2):264-9.

14. Qi Y, Kobayashi Y, Hulett FM. The pst operon of Bacillus subtilis has a phosphate-regulated promoter and is involved in phosphate transport but not in regulation of the pho regulon. J Bacteriol. 1997;179(8):2534-9.

15. Lee SJ, Pan JG, Park SH, Choi SK. Development of a stationary phasespecific autoinducible expression system in Bacillus subtilis. J Biotechnol. 2010;149(1-2):16-20.

16. Wenzel M, Muller A, Siemann-Herzberg M, Altenbuchner J. Self-inducible Bacillus subtilis expression system for reliable and inexpensive protein production by high-cell-density fermentation. Appl Environ Microbiol. 2011;77(18):6419-25.

17. Stefanic P, Decorosi F, Viti C, Petito J, Cohan FM, Mandic-Mulec I. The quorum sensing diversity within and between ecotypes of Bacillus subtilis. Environ Microbiol. 2012;14(6):1378-89.

18. Cosby WM, Vollenbroich D, Lee $\mathrm{OH}$, Zuber P. Altered srf expression in Bacillus subtilis resulting from changes in culture $\mathrm{pH}$ is dependent on the SpoOK oligopeptide permease and the ComQX system of extracellular control. J Bacteriol. 1998;180(6):1438-45.

19. Roggiani M, Dubnau D. ComA, a phosphorylated response regulator protein of Bacillus subtilis, binds to the promoter region of srfA. J Bacteriol. 1993;175(10):3182-7.

20. Schneider KB, Palmer TM, Grossman AD. Characterization of comQ and comX, two genes required for production of ComX pheromone in Bacillus subtilis. J Bacteriol. 2002;184(2):410-9.

21. Yazgan Karatas A, Çetin S, Özcengiz G. The effects of insertional mutations in comQ, comP, srfA, spoOH, spoOA and $a b r B$ genes on bacilysin biosynthesis in Bacillus subtilis. Biochimica et Biophysica Acta (BBA). 2003;1626(1-3):51-6.

22. Liu SL, Du K. Enhanced expression of an endoglucanase in Bacillus subtilis by using the sucrose-inducible sacB promoter and improved properties of the recombinant enzyme. Protein Expr Purif. 2012;83(2):164-8.

23. Gao X, Liu Z, Cui W, Zhou L, Tian Y, Zhou Z. Enhanced thermal stability and hydrolytic ability of Bacillus subtilis aminopeptidase by removing the thermal sensitive domain in the non-catalytic region. PLoS One. 2014;9(3):e92357.

24. Kleerebezem M, Bongers R, Rutten G, de Vos WM, Kuipers OP. Autoregulation of subtilin biosynthesis in Bacillus subtilis: the role of the spa-box in subtilin-responsive promoters. Peptides. 2004;25(9):1415-24.

25. Blazeck J, Alper HS. Promoter engineering: recent advances in controlling transcription at the most fundamental level. Biotechnol J. 2013;8(1):46-58

26. Dehli T, Solem C, Jensen PR. Tunable promoters in synthetic and systems biology. Subcell Biochem. 2012;64:181-201.

27. Leavitt JM, Alper HS. Advances and current limitations in transcript-level control of gene expression. Curr Opin Biotechnol. 2015;34C:98-104.

28. Phan TT, Nguyen HD, Schumann W. Development of a strong intracellular expression system for Bacillus subtilis by optimizing promoter elements. J Biotechnol. 2012;157(1):167-72.

29. Frisby D, Zuber P. Mutations in pts cause catabolite-resistant sporulation and altered regulation of $\mathrm{spoOH}$ in Bacillus subtilis. J Bacteriol. 1994;176(9):2587-95. 
30. Gao X, Cui W, Tian Y, Zhou Z. Over-expression, secretion, biochemical characterisation, and structure analysis of Bacillus subtilis aminopeptidase. J Sci Food Agric. 2013;93(11):2810-5.

31. Kang HK, Jang JH, Shim JH, Park JT, Kim YW, Park KH. Efficient constitutive expression of thermostable 4-alpha-glucanotransferase in Bacillus subtilis using dual promoters. World J Microbiol Biotechnol. 2010;26(10):1915-8.

32. Spizizen J. Transformation of biochemically deficient strains of Bacillus Subtilis by deoxyribonucleate. Proc Natl Acad Sci USA. 1958;44(10):1072-8.

33. Guan C, Cui W, He X, Hu X, Xu J, Du G, et al. Construction and development of a novel expression system of Streptomyces. Protein Expr Purif. 2015;113:17-22.

34. Li MZ, Elledge SJ. Harnessing homologous recombination in vitro to generate recombinant DNA via SLIC. Nat Methods. 2007;4(3):251-6.

35. Jeong JY, Yim HS, Ryu JY, Lee HS, Lee JH, Seen DS, et al. One-step sequence- and ligation-independent cloning as a rapid and versatile cloning method for functional genomics studies. Appl Environ Microbiol. 2012;78(15):5440-3

36. Miyazaki K, Takenouchi M. Creating random mutagenesis libraries using megaprimer PCR of whole plasmid. Biotechniques. 2002;33(5):1033-4 (1036-s8)
37. Bloor AE, Cranenburgh RM. An efficient method of selectable marker gene excision by Xer recombination for gene replacement in bacterial chromosomes. Appl Environ Microbiol. 2006;72(4):2520-5.

38. Yan X, Yu HJ, Hong Q, Li SP. Cre/lox system and PCR-based genome engineering in Bacillus subtilis. Appl Environ Microbiol. 2008;74(17):5556-62.

39. Botella E, Fogg M, Jules M, Piersma S, Doherty G, Hansen A, et al. pBaSysBioll: an integrative plasmid generating gfp transcriptional fusions for high-throughput analysis of gene expression in Bacillus subtilis. Microbiology. 2010;156:1600-8.

40. Wu XC, Lee W, Tran L, Wong SL. Engineering a Bacillus subtilis expressionsecretion system with a strain deficient in six extracellular proteases. J Bacteriol. 1991;173(16):4952-8.

41. Wu SC, Yeung JC, Duan Y, Ye R, Szarka SJ, Habibi HR, et al. Functional production and characterization of a fibrin-specific single-chain antibody fragment from Bacillus subtilis: effects of molecular chaperones and a wall-bound protease on antibody fragment production. Appl Environ Microbiol. 2002;68(7):3261-9.

\section{Submit your next manuscript to BioMed Central and take full advantage of:}

- Convenient online submission

- Thorough peer review

- No space constraints or color figure charges

- Immediate publication on acceptance

- Inclusion in PubMed, CAS, Scopus and Google Scholar

- Research which is freely available for redistribution

Submit your manuscript at

www.biomedcentral.com/submit

C Biomed Central 